Moorbath, S., Taylor, P. N. \& Goodwin, R. 1981: Origin of granitic magma by crustal remobilisation: $\mathrm{Rb}-\mathrm{Sr}$ and $\mathrm{Pb}-\mathrm{Pb}$ geochronology and isotope geochemistry of the late Archaean Qôrqut granite complex of southern West Greenland. Geochim. cosmichim. Acta 45, 1051-1069.

Nutman, A. P. 1982: Further work on the early Archaean rocks of the Isukasia area, southern West Greenland. Rapp. Grønlands geol. Unders. 110, 49-54.

Nutman, A. P., Bridgwater, D., Dimroth, E., Gill, R. C. O. \& Rosing, M. 1983: Field work on early $(3700 \mathrm{Ma})$ Archaean rocks of the Isua supracrustal belt and adjacent gneisses. Rapp. Grønlands geol. Unders. 112, 5-22.

H. B.,

University of Alberta,

Edmonton, Alberta,

Canada.
M. R. \& D. B., Geologisk Museum, Øster Voldgade 5-7, $D K-1350$ Copenhagen $K$.

A. P. N.,

Memorial University of Newfoundland,

St. John's, Newfoundland,

Canada.

\title{
Malene amphibolites and related anorthosites from Akugdlerssuaq, inner Godthåbsfjord, with komatiite affinities
}

\author{
Allen P. Nutman
}

Mapping by helicopter reconnaissance in 1976 (Allaart et al. 1977) and subsequent more detailed mapping in 1981 (Nutman, 1982) showed that there are several units of anorthosite with associated amphibolite on Akugdlerssuaq, inner Godthåbsfjord. The anorthosite and amphibolite units are interspersed with units of strongly deformed Amîtsoq gneisses (identified by the presence of basic dyke remains and by enclaves of banded iron formation) sheeted by younger gneisses. Most of the contacts between anorthosite and amphibolite units and the Amitsoq gneisses are clearly tectonic, whilst the remaining contacts could also be tectonic or are modified primary contacts (Nutman, 1982). The younger gneisses are of late Archaean age (Bridgwater \& Nutman, unpublished Rb-Sr isotopic data).

The field characters of the anorthosites and amphibolites were described by Nutman (1982). The most important points are summarised below:

The amphibolites are banded and contain lenses and discontinuous horizons of garnet-biotite-quartz-feldspar rock, possibly paragneiss. The anorthosites range from medium-grained varieties with distinct layering to a more homogeneous type consisting of a gabbroic matrix crowded with plagioclase megacrysts. The amphibolites and anorthosites are not intimately interlayered, but units up to a couple of hundred metres wide are adjacent to each other. In the west of the area, in an augen of low deformation, the anorthosite is suggested as having intruded, and locally reacted with garnet-biotite gneiss. The age relations between the anorthosites and amphibolites and the gneisses which intrude both are the same as those found in the Fiskenæsset and Buksefjorden regions (Kalsbeek \& Myers, 1973; Chadwick \& Coe, 
Table 3. Analyses of representative anorthosites and amphibolites, Akugdlerssuaq, inner Godthåbsfjord

\begin{tabular}{lrrrrrr}
\hline Sample & 292437 & 292462 & 292460 & 292427 & 292418 & 292428 \\
\hline $\mathrm{Sio}_{2}$ & 46.89 & 48.18 & 42.12 & 48.38 & 4871 & 48.81 \\
$\mathrm{TiO}_{2}$ & 0.09 & 0.33 & 0.33 & 0.55 & 0.59 & 0.59 \\
$\mathrm{Al}_{2} \mathrm{O}_{3}$ & 25.34 & 26.28 & 26.27 & 25.20 & 15.80 & 15.22 \\
$\mathrm{Fe}_{2} \mathrm{O}_{3}$ & 2.17 & 0.81 & 3.33 & 2.36 & 2.34 & 2.42 \\
$\mathrm{FeO}$ & 3.36 & 3.43 & 6.76 & 8.58 & 8.70 & 8.77 \\
$\mathrm{MnO}$ & 0.08 & 0.05 & 0.16 & 0.19 & 0.18 & 0.18 \\
$\mathrm{MgO}$ & 3.74 & 2.95 & 4.23 & 8.53 & 8.17 & 7.96 \\
$\mathrm{CaO}$ & 10.02 & 13.04 & 7.51 & 10.92 & 10.67 & 10.58 \\
$\mathrm{Na}{ }_{2} \mathrm{O}$ & 3.01 & 1.44 & 0.46 & 2.17 & 1.81 & 1.79 \\
$\mathrm{~K}_{2} \mathrm{O}$ & 1.59 & 0.30 & 3.00 & 0.78 & 0.59 & 0.98 \\
$1.0 . \mathrm{i}$. & 3.32 & 1.22 & 4.46 & 1.87 & 2.28 & 2.37 \\
$\mathrm{P} \mathrm{O}_{5}$ & 0.01 & 0.03 & 0.04 & 0.04 & 0.04 & 0.04 \\
& 99.62 & 98.06 & 98.67 & 99.57 & 99.88 & 99.71 \\
$\mathrm{Rb}$ & 75 & 7 & 168 & 17 & 36 & 52 \\
$\mathrm{Sr}$ & 250 & 134 & 235 & 70 & 54 & 104 \\
$\mathrm{Ba}$ & 317 & 40 & 648 & 86 & 51 & 148 \\
$\mathrm{Y}$ & 3.5 & 5 & 13 & 19 & 20 & 21 \\
$\mathrm{Zr}$ & 5.1 & 12 & 119 & 30 & 33 & 37 \\
$\mathrm{Ni}$ & 84 & 35 & 80 & 164 & 170 & 147 \\
$\mathrm{Cr}$ & 15 & 208 & 66 & 401 & 447 & 311 \\
\hline
\end{tabular}

$292437 \& 292462$ anorthosites, 292460 anorthosite contaminated by country rocks, 292427,292418 and 292428 amphibolites.

1.o.i. loss on ignition.

1983), and the rocks are regarded as chronostratigraphically equivalent (see Table 1 of McGregor et al., 1983, for the sequence of geological events in the region). The rocks of Akugdlerssuaq are in amphibolite facies, and there is no evidence to suggest that they have previously been affected by late Archaean granulite facies metamorphism.

\section{Geochemistry}

Twenty-three samples from the westernmost unit of anorthosite and amphibolite on Akugdlerssuaq (zone II in Nutman, 1982) were analysed for major elements at GGU and for selected trace elements by John Bailey, Petrological Institute, University of Copenhagen. Representative analyses are given in Table 3. Analytical methods, values for international standards and further analyses are available upon request. Samples used in this study were taken as far away as possible from shear zones and intrusive gneiss sheets.

Before consideration of the igneous evolution of the anorthosites and amphibolites on the basis of geochemical data, it is important to ascertain how much of the chemistry of the rocks is inherited from their igneous protoliths and how much is a reflection of metasomatism dur- 

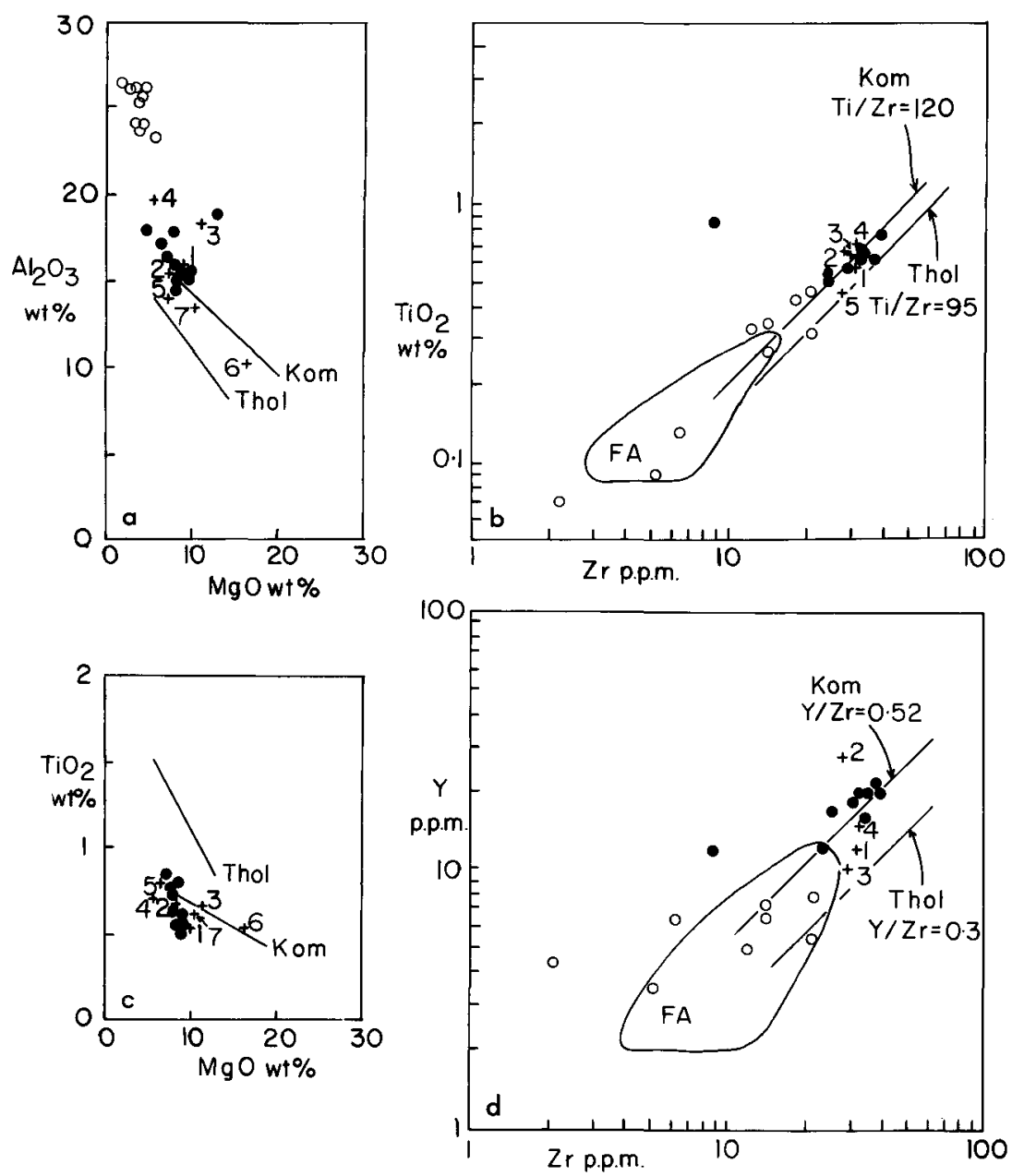

Fig. 18. $\mathrm{TiO}_{2}, \mathrm{Al}_{2} \mathrm{O}_{3}, \mathrm{MgO}, \mathrm{Y}$ and $\mathrm{Zr}$ variation of Akugdlerssuaq amphibolites, anorthosites and comparative rocks. - Akugdlerssuaq amphibolite and $O$ anorthosite. Field FA is for Fiskenæsset anorthosites (Weaver $e t$ al., 1981) and 1 is average of 10 low-Zr amphibolites from Fiskenæsset (Weaver $e$ t al., 1981). Numbers 1 to 5 are averages of Malene amphibolite lithotypes (Chadwick, 1981), and 6 and 7 averages of Malene high-Mg and low-Mg amphibolites respectively (Hall, 1980). Thol and Kom are liquid trends for Abitibi picrite-tholeiite and komatiite units (Arndt et al., 1977).

ing regional metamorphism and intrusion of younger gneisses. In the anorthosites and amphibolites there is an irregular variation between LREE (light rare earth element), Rb, Ba, $\mathrm{Pb}$, Th and $\mathrm{K}_{2} \mathrm{O}$ versus $\mathrm{MgO}$ content. Thus it is evident that the geochemistry of these rocks cannot be solely accounted for by igneous fractionation processes that gave rise to their protoliths. Studies of the adjacent Amitsoq gneisses suggest that LREE, Rb, $\mathrm{Ba}, \mathrm{Pb}, \mathrm{Th}$ and $\mathrm{K}_{2} \mathrm{O}$ were mobile on a regional scale during late Archaean high-grade metamorphism and intrusion of gneiss sheets (Nutman \& Bridgwater, unpublished data). Nesbitt \& Sun (1976) concluded that $\mathrm{TiO}_{2}, \mathrm{Zr}$ and $\mathrm{Y}$ are relatively immobile during regional metamorphism and 
alteration, whilst $\mathrm{MgO}$ and $\mathrm{A1}_{2} \mathrm{O}_{3}$ are also considered relatively immobile during high-grade metamorphism (e.g. Wells, 1979). For the anorthosites and amphibolites of Akugdlerssuaq these components when plotted form fairly well defined trends against each other (fig. 18); these trends resemble those found in less recrystallised suites of igneous rocks (e.g. data in Nesbitt \& Sun, 1976), and are regarded as a first approximation of the igneous variation in the protoliths of the amphibolites and the anorthosites.

$\mathrm{MgO}-\mathrm{Al}_{2} \mathrm{O}_{3}$ (fig. 18). The anorthosites form a cluster at high $\mathrm{A}_{2} \mathrm{O}_{3}$ and low $\mathrm{MgO}$ content, reflecting their high cumulate plagioclase content. The amphibolites form a cluster around $c .8 \mathrm{wt} \% \mathrm{MgO}, 16 \mathrm{wt} \% \mathrm{A1}_{2} \mathrm{O}_{3}$, with a linear scatter of a few samples that have higher $\mathrm{Al}_{2} \mathrm{O}_{3}$ and lower $\mathrm{MgO}$ content.

$\mathrm{TiO}_{2}-\mathrm{Zr}$ (fig. 18). The anorthosites and the amphibolites form a linear scatter of $\mathrm{Ti} / \mathrm{Zr}$ value of $c .120$. There is no overlap in the scatter between the amphibolites (higher $\mathrm{TiO}_{2}$ and $\mathrm{Zr}$ content) and the anorthosites.

$\mathrm{MgO}-\mathrm{TiO}_{2}$ (fig. 18). The amphibolites have a low $\mathrm{TiO}_{2}$ content for a given $\mathrm{MgO}$.

$Y$-Zr (fig. 18). The amphibolites scatter close to a $\mathrm{Y} / \mathrm{Zr}=0.5$ line. The anorthosites show greater scatter on the plot than the amphibolites (which have higher Y contents). Increasing scatter with low $Y$ content could be due to lower precision in determining $Y$ when present in low abundance. There is perhaps a tendency for $\mathrm{Y} / \mathrm{Zr}$ to increase with decreasing $\mathrm{Zr}$ content. This is to be expected in a mixture of plagioclase cumulate and intercumulus basic liquid, because $\mathrm{Y}$ is admitted into plagioclase crystals.

$\mathrm{FeO}^{\mathrm{tot}} / \mathrm{MgO}$ varies from $c .1$ to 1.5 in the amphibolites and anorthosites. Higher $\mathrm{FeO}^{\mathrm{to}} /$ $\mathrm{MgO}$ can in some cases in the anorthosites be correlated with higher $\mathrm{Ba}$ and $\mathrm{K}_{2} \mathrm{O}$ content; some of this type of sample were regarded in the field as anorthosite contaminated by assimilation of biotite-garnet gneiss (e.g. sample 292460, Table 3).

The variation of $\mathrm{Al}_{2} \mathrm{O}_{3}, \mathrm{MgO}, \mathrm{TiO}_{2}, \mathrm{Zr}$ and $\mathrm{Y}$ in the anorthosites and amphibolites from Akugdlerssuaq resembles that of the anorthosites and low- $\mathrm{Zr}$ amphibolites in the Fiskenæsset region (Weaver et al., 1981). Using partition coefficients derived by Pearce \& Norry (1979), Weaver et al. (1981) argued that the $\mathrm{TiO}_{2}, \mathrm{Y}$ and $\mathrm{Zr}$ variations for the amphibolites and anorthosites from the Fiskenæsset region show that they are consanguineous and that plagioclase was the only significant accumulated phase in most stratigraphic levels of the anorthosite units. Weaver et al. (1981) also pointed out the high $\mathrm{A1}_{2} \mathrm{O}_{3}$ for a given $\mathrm{MgO}$ content and the low abundance of $\mathrm{Zr}, \mathrm{Y}$ and $\mathrm{TiO}_{2}$ in the parental magma of the Fiskenæsset anorthosites, and the low- $\mathrm{Zr}$ amphibolites with which they were considered to be related. The same observations and deductions can be made about the rocks from Akugdlerssuaq; namely that they are consanguineous and were derived from a parental magma of high $\mathrm{A}_{2} \mathrm{O}_{3}$ for given $\mathrm{MgO}$ content. Chronostratigraphically equivalent Malene amphibolites described by Chadwick (1981) and Hall (1980) include varieties with similar chemistry to the Akugdlerssuaq amphibolites (fig. 18), as well as groups of iron-rich tholeiitic composition.

The amphibolites from Akugdlerssuaq are not cumulate-rich rocks, and may approximate to liquid compositions. Along with other Malene amphibolites and amphibolites from Fiskenæsset, they are compared here with well-documented liquid compositions of iron-rich 
tholeiite and komatiite affinity from the mid-Archaean Abitibi volcanosedimentary belt of Ontario (Arndt et al., 1977; Sun \& Nesbitt, 1978) (fig. 18). The Akugdlerssuaq amphibolites, then low-Zr amphibolites from Fiskenæsset (Weaver et al., 1981) and some Malene amphibolites of Chadwick (1981) have compositions resembling Abitibi basaltic komatiites; in addition Hall (1980) described groups of amphibolites resembling pyroxenitic and basaltic komatiites in composition (fig. 18). There are also some Malene amphibolites of iron-rich tholeiite affinity (Chadwick, 1981, and fig. 18).

Hall \& Friend (1979) suggest that the 'oceanic' affinities of Malene amphibolites is evidence that they were part of ensimatic crust. However, Gill \& Bridgwater (1979) showed that the mid-Archaean Ameralik dykes that cut early Archaean continental crust have compositional characters of 'oceanic' basalts. It is also interesting to note that some sets of Ameralik dykes also have high $\mathrm{Al}_{2} \mathrm{O}_{3}$ for a given $\mathrm{MgO}$ content and low $\mathrm{Zr}$ and $\mathrm{TiO}_{2}$ abundances compared with iron-rich tholeiites (e.g. samples 173277, 173278, 171754 and 158440 in Gill \& Bridgwater, 1979). It is possible that at least some of the Ameralik dykes could have been feeders to Malene volcanism (Chadwick, 1981; Nutman \& Bridgwater, 1983). Furthermore, komatiites and compositionally similar Phanerozoic rocks such as boninites and some ophiolites are argued by some workers not to be representative of typical oceanic crust, but can be formed in intra-sialic rifts or fore-arc basins (Cameron \& Nisbet, 1981; Nisbet, 1981).

Therefore the 'oceanic' chemistry of Malene amphibolites is not evidence against proposals that some Malene rocks were erupted onto, and adjacent to continental crust, represented by the early Archaean Amîtsoq gneisses (Chadwick \& Nutman, 1979; Chadwick, 1981; Nutman \& Bridgwater, 1983).

Acknowledgements. I thank Vic McGregor for introducing me to the geology of the Akugdlerssuaq area as one of special interest, David Bridgwater for discussions on the geology of the area and for arranging for analyses of the samples, and Brian Fryer for comments on the report.

\section{References}

Allaart, J. H., Jensen, S. B., McGregor, V. R. \& Walton, B. J. 1977: Reconnaissance mapping for the 1:500 000 map sheet in the Godthåb-Isua region, southern West Greenland. Rapp. Grønlands geol. Unders. 85, 50-54.

Arndt, N. T., Kaldrett, A. J. \& Pyke, D. R. 1977: Komatiitic and iron-rich tholeiitic lavas of Munro Township, Northeast Ontario. J. Petrol. 18, 319-369.

Cameron, W. E. \& Nisbet, E. G. 1981: Phanerozoic analogues of komatiitic basalts. In Arndt, N. T. \& Nisbet, E. G. (edit.) Komatiites. 526 pp. London: Allen \& Unwin.

Chadwick, B. 1981: Field relations, petrography and geochemistry of Archaean amphibolite dykes and Malene supracrustal amphibolites, northwest Buksefjorden, southern West Greenland. Precambrian Res. 14, 221-259.

Chadwick, B. \& Coe, K. 1983: Descriptive text to 1:100 000 sheet Buksefjorden 63 V.1 Nord. 70 pp. Copenhagen: Grønlands geol. Unders.

Chadwick, B. \& Nutman, A. P. 1979: Archaean structural evolution in the northwest of the Buksefjorden region, southern West Greenland. Precambrian Res. 9, 199-226.

Gill, R. C. O. \& Bridgwater, D. 1979: Early Archaean basic magmatism in West Greenland: the geochemistry of the Ameralik dykes. J. Petrol. 20, 695-726.

Hall, R. P. 1980: The tholeiitic and komatiitic affinities of the Malene metavolcanic amphibolites from Ivisârtoq, southern West Greenland. Rapp. Grønlands geol. Unders. 97, 20 pp. 
Hall, R. P. \& Friend, C. R. L. 1979: Structural evolution of the Archean rocks in Ivisârtoq and the neighbouring inner Godthåbsfjord region, southern West Greenland. Geology 7, 311-315.

Kalsbeek, F. \& Myers, J. S. 1973: The geology of the Fiskenæsset region. Rapp. Grønlands geol. Unders. 51, 5-18.

McGregor, V. R., Bridgwater, D. \& Nutman, A. P. 1983: The Qârusuk acid dykes: post-Nûk, pre-Qôrqut magmatism in the Godthåb region, southern West Greenland. Rapp. Grønlands geol. Unders. 112, 101-112.

Nesbitt, R. W. \& Sun, S. S. 1976: Geochemistry of Archaean spinifex-textured peridotites and magnesian and low magnesian tholeiites. Earth planet. Sci. Lett. 31, 433-454.

Nisbet, E. G. 1981: The tectonic setting and petrogenesis of komatiites. In Arndt, N. T. \& Nisbet, E. G. (edit.) Komatiites. 526 pp. London: Allen \& Unwin.

Nutman, A. P. 1982: Investigations on amphibolite facies orthogneisses, amphibolites and leucogabbros on Akugdlerssuaq, inner Godthåbsfjord. Rapp. Grønlands geol. Unders. 110, 72-77.

Nutman, A. P. \& Bridgwater, D. 1983: Deposition of Malene supracrustal rocks on an Amîtsoq basement in outer Ameralik, southern West Greenland. Rapp. Grønlands geol. Unders. 112, 43-51.

Pearce, J. A. \& Norry, M. J. 1979: Petrogenetic implications of Ti, Zr, Y and Nb variations in volcanic rocks. Contrib. Mineral. Petrol. 69, 33-47.

Sun, S. S. \& Nesbitt, R. W. 1978: Petrogenesis of Archaean ultrabasic and basic volcanics: evidence from rare earth elements. Contrib. Mineral. Petrol. 65, 301-325.

Weaver, B. L., Tarney, J. \& Windley, B. F. 1981: Geochemistry and petrogenesis of the Fiskenæsset anorthosite complex, southern West Greenland: nature of the parent magma. Geochim. cosmochim. Acta. 45, 711-725.

Wells, P. R. A. 1979: Chemical and thermal evolution of Archaean sialic crust, southern West Greenland. J. Petrol. 20, 187-226.

A.P.N., Memorial University of Newfoundland, St. John's, Newfoundland, Canada.

\title{
Geological mapping and mineral exploration in the Motzfeldt Centre of the Igaliko nepheline syenite complex, South Greenland
}

\author{
Tapani Tukiainen
}

The mineral occurrences of the Motzfeldt Centre, discovered by the South Greenland regional uranium exploration programme (Armour-Brown et al., 1984, Tukiainen et al., 1984), are now being explored for their $\mathrm{Nb}$ and Ta potential under a project financed by the EEC's Resources and Raw Materials Programme and The Geological Survey of Greenland. Accompanying the mineral exploration several other investigations are being carried out, and there is a close co-operation between the various groups working in the area.

The 1984 field activities comprised geological mapping, geochemical and geophysical investigations, and mineral exploration. The field activities were supported by GGU's facilities at Narssarssuaq where Jørgen Lau acted as base camp manager. A Jet Ranger helicopter, chartered on an ad hoc basis from the Ice Reconnaissance Centre at Narssarssuaq, was used for camp moves, geological reconnaissance and servicing of the field teams. De- 